\title{
HABITAT MANAGEMENT FOR CAPERCAILLIE TETRAO UROGALLUS L. LEKS: THE SURVEY OF VEGETATION CHANGES
}

\author{
Inga Straupe, Līga Liepa, Anete Anna Zālīte \\ Latvia University of Life Sciences and Technologies, Latvia \\ inga.straupe@1lu.lv
}

\begin{abstract}
The capercaillie Tetrao urogallus L. is a typical bird species inhabiting structurally diverse coniferous forests. To increase the habitat quality of capercaillie leks, experimentally the habitat restoration in degraded ecosystems has been practiced. The main habitat restoration events are related to the reversion of hydrological regime and understorey layer management. The aim of this study was to find out how the management of lek sites - mowing of Ledum palustre L. and ground vegetation - promotes the regeneration of the vegetation typical of the capercaillie leks. Three sample plot blocks of 10x30 m have been established, which have been divided into 3 variants of 10x10 m. The first is a control plot, in the second plot an entire ground vegetation mowing was performed, while in the third plot - the ground vegetation mowing in a $3 \mathrm{~m}$ wide strip was carried out. The vegetation was determined using the BraunBlanquet recording form before the management - in August 2015, and after the management - in August 2017. The condition of the habitat of capercaillie is inadequate before management, since Ledum palustre prevails in the ground vegetation. Both types of ground vegetation management have had a significant impact on the projective cover of Ledum palustre. After mowing the entire area, it has decreased by half, but after mowing in a strip, it has decreased by $30 \%$. The ground vegetation mowing in a strip enhances positively the regeneration of dwarf shrubs and herbaceous vegetation.
\end{abstract}

Key words: Tetrao urogallus L., Ledum palustre L., habitat management, mowing of ground vegetation.

\section{Introduction}

The capercaillie Tetrao urogallus L. is the world's largest ground-nesting grouse species inhabiting the boreal forest landscape, with a specific preference for raised bog, old and bog-type forest patches. It is a typical bird species inhabiting structurally diverse coniferous forests, and it has a complex social structure of the population (Kalniņš, 1958; Hofmanis \& Strazds, 2004). Therefore, capercaillie has been prioritized as umbrella species for indicating biodiversity qualities in the forest ecosystems (Pēterhofs, 2018). The capercaillie may show the changes in habitat use due to seasonality. However, during the winter time and early spring season birds utilize old-growth pinedominated forest stands, and in the summer - dwarf shrubs, especially, bilberry areas (Vaccinium myrtillus L.) and insect-rich spruce forests (Spidsø \& Stuen, 1988; Storch, 1993). In addition, breeding females prefer bog woodlands where cottongrass (Eriophorum spp.) is available. Furthermore, broods have been showed to positively associate with closed canopy in swamp forests with high invertebrate richness.

The capercaillie is red-listed species in many European countries. It is known that in the last decades many local populations of capercaillie have declined throughout the western and central European countries (Saniga, 2003), while recently the decrease in populations has also been recorded in Belarus (Zizas et al., 2012), Fennoscandia (Lindén, 2002) and Baltic countries (Lõhmus et al., 2017). Despite this, the present core area of the populations is in the western part of Russia and Fennoscandia. The underlying causes of population decline and, in some regions even extinctions, are still unclear, but most of the studies highlight the negative impact of human-induced changes in the forest landscape (especially, forest habitat fragmentation, isolation, loss of connectivity), the impact of climate change and rising temperature, and higher predation pressure. Also, the spatial requirements for capercaillie leks may consist of large areas, where males are using an area of at least 300 ha (Rolstad \& Wegge, 1989). In Latvia, the conservation of capercaillie is aimed at the preservation of the forest stand level approach where 'lek-center' with an entire area, including buffers, is protected, also called micro-reserves. Furthermore, in Latvia, the area from strictly to voluntary protected lek sites is estimated as approximately 45.159 ha (Lõhmus et al., 2017).

Over the last decade, the forest and semi-open wetland drainage has been widely practiced in the northern temperate and boreal forests to increase the timber yields and reach sites for timber resources (Vasander et al., 2003). The recent calculation shows that in Latvia approximately $40 \%$ of peatland forests around the leks are classified as drained forest types, whereas the proportion of clear-cuts around leks are insignificant (Lõhmus et al., 2017). To increase the habitat quality of capercaillie leks, experimentally the habitat restoration in degraded ecosystems has been practiced. The main habitat restoration events are related to the reversion of hydrological regime (e.g. blocking ditches to raise water table) and understorey, and canopy layer management (e.g., mowing, burning or tree layer removal) (Hancock et al., 2011; Vasander et al., 2003). 
The aim of this study was to find out how the management of lek sites - mowing of Ledum palustre L. and ground vegetation - promotes the regeneration of the vegetation typical of the capercaillie leks. In order to achieve the aim, the following tasks have been set: to characterize the vegetation of peatland pine forest stand in the lek of capercaillie before management, as well as to characterize and compare the ground vegetation of these stands after different types of management. Therefore, we hypothesize that the management of the capercaillie lek sites - mowing of the ground vegetation, especially, Ledum palustrecontributes to the regeneration of the ground vegetation typical of the pine peatlands.

\section{Materials and Methods}

The study was conducted in Latvia, which belongs to the boreo-nemoral vegetation zone. The mean air temperature in February is $-3.6{ }^{\circ} \mathrm{C}$ and $16.9^{\circ} \mathrm{C}$ in July. The climate is characterized from transitional maritime to continental toward the eastern part of the country. The average yearly precipitation is approximately $700 \mathrm{~mm}$. The dominating tree species include Scots pine Pinus sylvestris L., silver birch Betula pendula Roth. and downy birch Betula pubescens Ehrh., Norway spruce Picea abies (L.) H. Karst., black alder Alnus glutinosa (L.) Gaertn., grey alder Alnus incana (L.) Moench., common aspen Populus tremula L., and broad-leaved species, whereas forest covers approximately $52 \%$ of the territory.

The studied capercaillie lek site is located in Plāṇi rural municipality of Strenči county (Figure 1). The microreserve of the lek was established in 2003, with a total area of 167.7 ha having a buffer zone of 34.7 ha, characterized by different age classes of stands (70180 years) dominated by Scots pine with an admixture of downy birch and Norway spruce. The number of breeding males for an area is from three to four.

Forest land drainage has been carried out in the area, so it is crossed by several ditches that have overgrown over time, but they have fulfilled their function, and the forest stands have become more productive whereas Norway spruce has often been detected. The drainage has also made changes in the ground vegetation, and currently Ledum palustre can be found over a wide territory, which in some places reaches the height of more than $1 \mathrm{~m}$.

Three sample plot blocks have been established in the object or three repetitions of 10x30 m which have been divided into 3 subplots or variants of $10 \times 10 \mathrm{~m}$. In each variant, different ground vegetation management was performed during the vegetation period of 2015 . The first is a control plot (control) where ground vegetation management or mowing was not carried out. In the second plot (management variant 1), an entire ground vegetation mowing was performed, while in the third plot (management variant 2) ground vegetation mowing in a $3 \mathrm{~m}$ wide strip - in the center of the sample plot was carried out. Five $1 \mathrm{x} 1 \mathrm{~m}$ square sample plots are located on the diagonal of the sample plot at certain distances - $1.4 \mathrm{~m} ; 4.2 \mathrm{~m} ; 7.0 \mathrm{~m}$; $9.8 \mathrm{~m}$ and $12.6 \mathrm{~m}$. The vegetation was determined in the sample plots using the Braun-Blanquet recording form (Muller-Dombois \& Ellenberg, 1974) before the management - in August 2015 and after the management - in August 2017. The block scheme of sample plots is shown in Figure 2.

For each species, the mean projective cover has been determined using the data from $1 \times 1 \mathrm{~m}$ sample plots. For plant species, a coefficient of occurrence was calculated according to Raunkier, which describes how frequently a given species is represented in all the investigated plots in total. The occurrence of plant species is equated to the parameter of consistency, determined by attributing it to the occurrence coefficient: I $-<21$, II - $21-40$, III - $41-60$, IV - 61 - 80, V - 81 - 100\% (Muller-Dombois \& Ellenberg, 1974).

For the comparison of the changes in species in different management variants, the Jacquard similarity
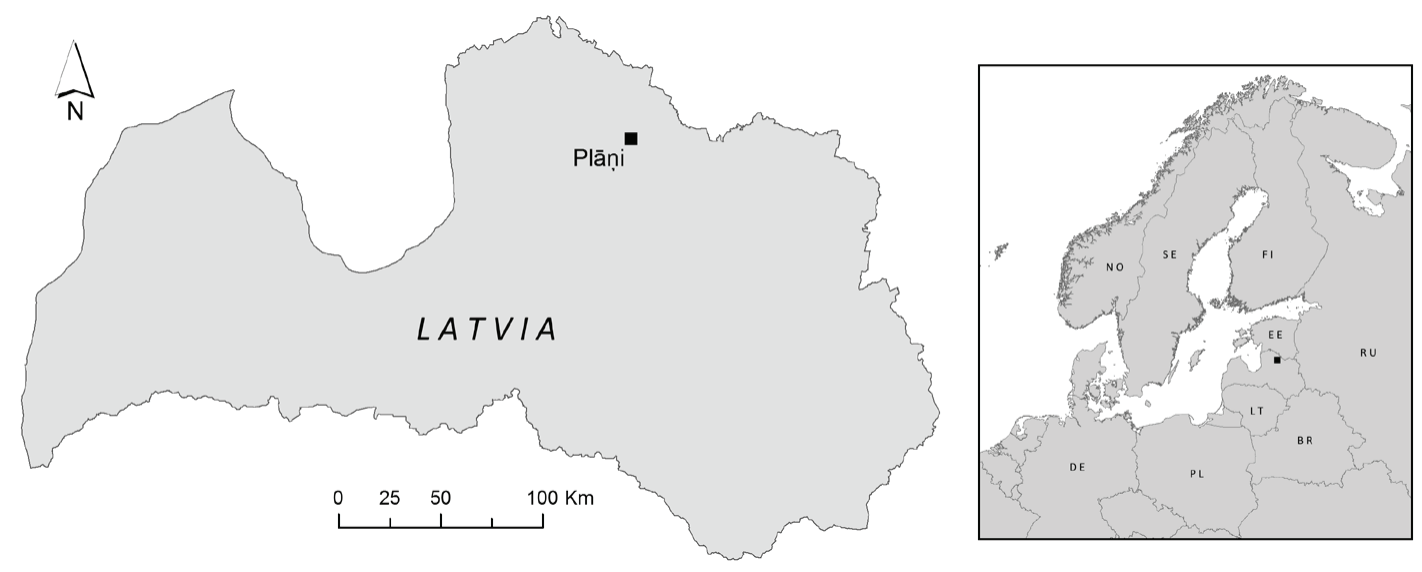

Figure 1. The location of the studied area. 


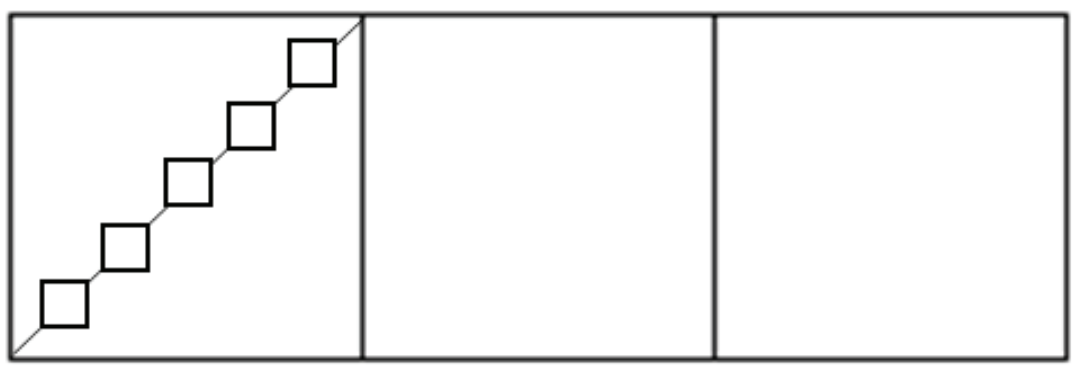

$10 \mathrm{~m}$

\section{$30 \mathrm{~m}$}

Figure 2. The block scheme of sample plots.

coefficient $(\mathrm{J})$ was tested, which characterizes the number of species shared by two categories and the number of species unique to each category (commonly, these counts are marked as A, B and C) (Krebs, 1989).

$$
J=\frac{A}{A+B+C}
$$

T-test was used to analyze the data before and after the management (Arhipova \& Bālina, 2006). Comparison of the mean projective cover of species depending on the management variant was carried out. A risk level of $5 \%(\mathrm{P}<0.05)$ was used to define statistical significance. Data calculation was performed in MS Excel.

\section{Results and Disscussion}

Prior to the habitat management in 2015, the registration of ground vegetation species and their projective cover assessment were carried out in leks (Figure 3). In both layers - dwarf shrubs and herbaceous layer, as well as in the moss and lichen vegetation layer, nine species were identified: Andromeda polifolia L., Calluna vulgaris (L.) Hull, Empetrum nigrum L., Eriophorum vaginatum L., Ledum palustre L., Oxycoccus palustris Pers., Vaccinium myrtillus L., Vaccinium uliginosum L., Vaccinium vitis-idaea L. and Aulacomnium palustre (Hedw.) Schwagr., Sphagnum magellanicum Brid., Dicranum polysetum Sw. Ex anon. Sphagnum capillifolium (Ehrh.) Hedw., Sphagnum palustre L., Pleurozium schreberi (Brid.) Mitt., Hylocomium splendens (Hedw.) Shcrimp., Cladina stygia (Fr.) Ruoss, Cladina arbuscula (Wallr.) Rabenh. The most common species prior to the management are Ledum palustre, Eriophorum vaginatum, Pleurozium schreberi and Sphagnum capillifolium, which are the characteristic species of bog woodlands dominated by Scots pine (Ikauniece, 2017).

Before habitat management, the highest species cover was found for Ledum palustre $(36.9 \pm 1.8 \%)$

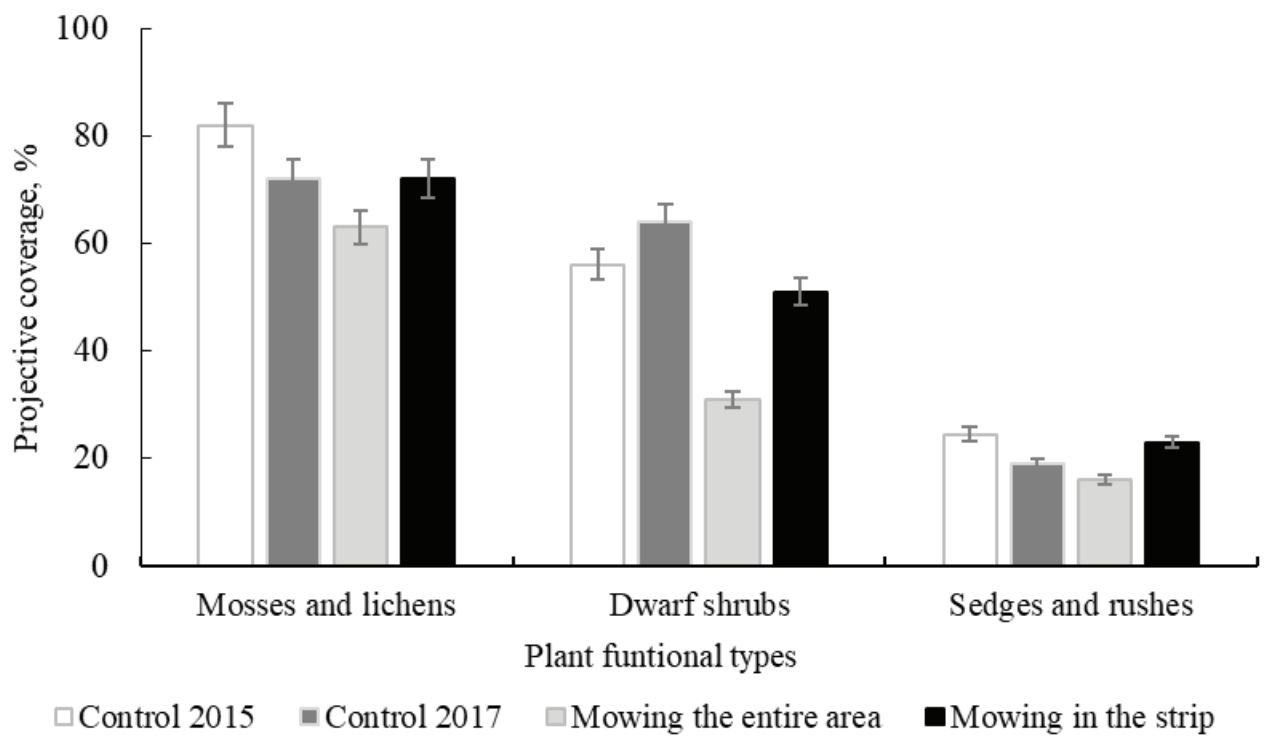

Figure 3. Plant functional type composition of the ground layer by management category. Mean projective coverage for each type, error bars indicate SE. 
and Eriophorum vaginatum $(24.5 \pm 1.2 \%)$. The largest projective cover of mosses and lichens are Pleurozium schreberi $(30.1 \pm 1.5 \%)$, Sphagnum capillifolium $(28.2 \pm 1.4 \%)$ and Sphagnum magellanicum (13.9 \pm $0.7 \%$ ). For the other species in both vegetation layers the mean projective cover does not exceed $4 \%$.

After the habitat management, data were collected in 2017. In total 10 species were recorded in the dwarf shrub and herbaceous layer, while 11 species were registered for mosses and lichens: apart from the species registered before, the presence of Drosera rotundifolia L., Cladonia fimbriata (L.) Fr. and Polytrichum juniperum Hedw. was found there. The highest occurrence of the following species was recorded in ground layer: Ledum palustre, Eriophorum vaginatum and Oxycoccus palustris, as well as Pleurozium schreberi and Sphagnum capillifolium.

After the management, in dwarf shrub and herbaceous layer the occurrence of Ledum palustre has decreased but with regard to other species, it has increased. In the layer of mosses and lichens, overall, for the species the occurrence has increased, but two species have been established only after the performed management practice. Cladonia fimbriata has been observed in shady areas, but Polytrichum juniprum in open and semi-open patches. In literature it has been mentioned as a pioneer species, established after a natural disturbance (Strazdina et al., 2011).

In the controls, a significant projective cover is occupied by Ledum palustre $(40.7 \pm 2.0 \%)$ (Figure 4$)$ and Eriophorum vaginatum $(19 \pm 1.0 \%)$. In the layer of mosses and lichens, Pleurozium schreberi (28 \pm
$1.4 \%)$ and also Sphagnum capillifolium $(27.1 \pm 1.4 \%)$ constitute the large proportion of coverage.

In the sample plots where mowing of the entire area was performed, Ledum palustre and Eriophorum vaginatum occupy the largest mean projective cover, however Ledum palustre cover has reduced significantly by half $(19.1 \pm 1.0 \%)$ (Figure 4$)$, but coverage of Eriophorum vaginatum was decreased insignificantly (on average by $16 \pm 0.8 \%$ ). This can be explained by the morphology of Eriophorum vaginatum, since it grows in clusters and regenerates in the clustering node, which is not affected during mowing. For several sphagnum and mosses, such as Sphagnum capillifolium, $20 \pm 1.0 \%$, forms the largest projection cover in the moss and lichen layer followed by Pleurozium schreberi $(19 \pm 1.0 \%)$, Dicranum polysetum $(9.7 \pm 0.5 \%)$ and Sphagnum magellanicum $(8.9 \pm 0.4 \%)$, but the absence of lichens was observed after habitat management.

In the sample plots where mowing was carried out in a strip, all above mentioned species are present in the ground vegetation layers. The largest projective covers, as before, are those of Ledum palustre and Eriophorum vaginatum. Ledum palustre projective cover (Figure 4) has decreased significantly $(\mathrm{p}<0.05)$ by $30 \%$, while Eriophorum vaginatum has the highest cover here $(21.2 \pm 1.1 \%)-10 \%$ higher than in the control sample plot and moderately higher than after mowing the entire area (Figure 4).

The results show that the management significantly affects the development of Ledum palustre after both mowing the entire ground vegetation and also after

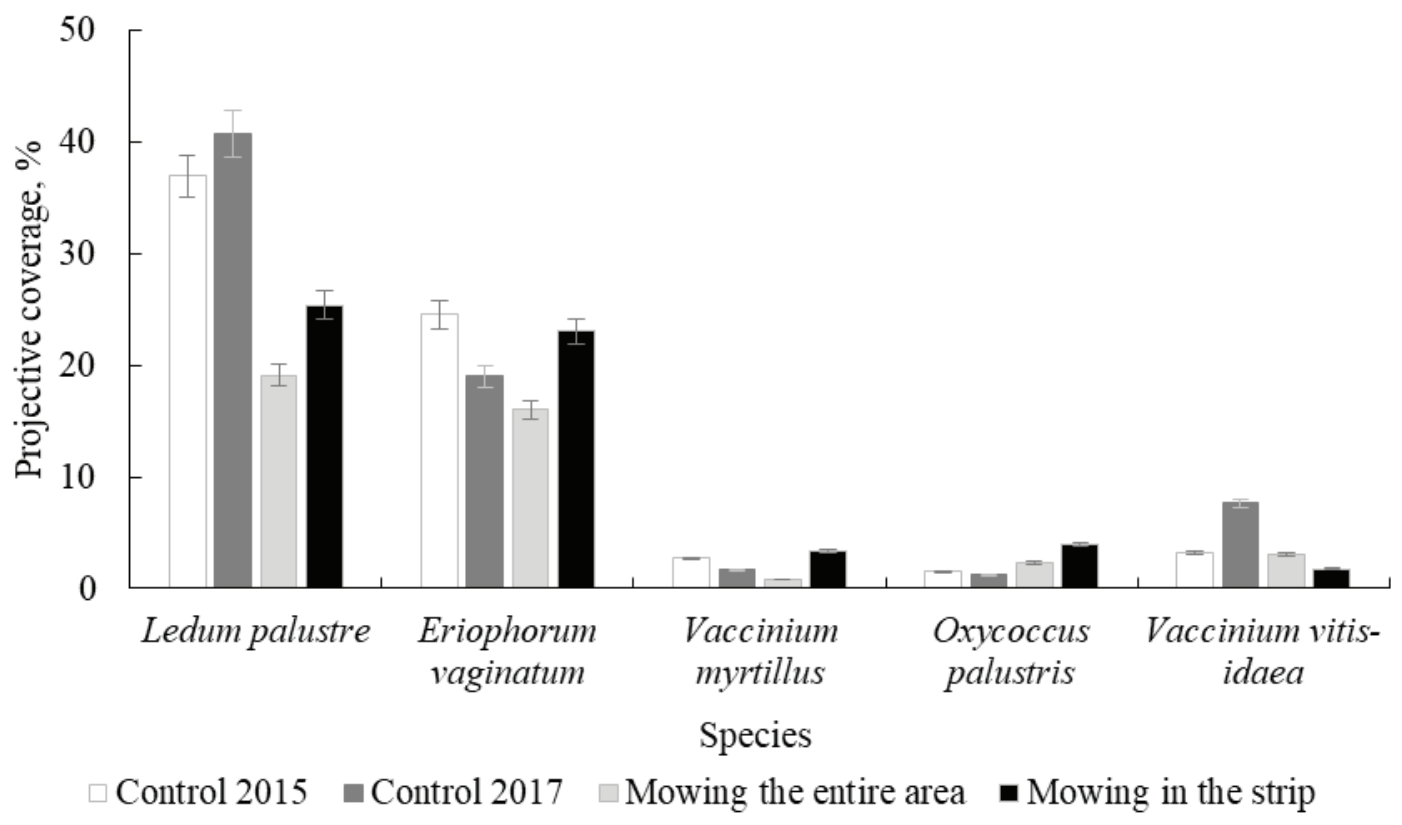

Figure 4. The projective coverage of Ledum palustre, Eriophorum vaginatum, Vaccinium myrtillus, Oxycoccus palustris and Vaccinium vitis-idaea. Mean projective coverage for each species by management category, error bars indicate SE. 
mowing in a strip $(\mathrm{p}<0.05)$. There is also a significant difference in the development of Oxycoccus palustris after the entire ground vegetation mowing $(\mathrm{p}<0.05)$. The projective cover of Oxycoccus palustris, which is an important nutrient base species for capercaillie, increases significantly both after the entire area mowing and after mowing in a strip, but it decreases in the control sample plot, where Ledum palustre is a competitor with plant species and is one of the disturbing factors during the capercaillie breeding period, since it reaches the height of $71 \pm 3.5 \mathrm{~cm}$, which exceeds the height of ground vegetation suitable for capercaillie - $40 \mathrm{~cm}$ (Strazds et al., 2010). Coverage for Oxycoccus palustris rises only a few centimeters above the ground, so it has not been affected by mowing and it has been able to continue to grow and develop. The highest coverage of Oxycoccus palustris has been recorded just after the ground vegetation mowing in a strip, where the species coverage raised (Figure 4).

For the comparison of the changes in species in different management variants, the Jacquard similarity coefficient was determined. The changes were found in the dwarf shrub and herbaceous layer, comparing the control sites and those sites where an entire area mowing was performed $(\mathrm{J}=0.65)$, while the smallest changes were observed when comparing the control sites with sites where the mowing of ground vegetation was performed in a strip $(\mathrm{J}=0.85)$. It has been found that the species coverage of the tree layer affects the projective cover of Ledum palustre: with the increase in the tree layer projective cover, the projective cover of Ledum palustre decreases, while with the decrease in the projective cover of the tree layer, the projective cover of Ledum palustre increases (Figure 4).

\section{Conclusions}

1. The ground coverage of the habitat of capercaillie in the investigated breeding period before management is unsuitable, since Ledum palustre prevails in the ground vegetation. Its height is higher than the height of the ground cover suitable for capercaillie.

2. The ground vegetation management has contributed to the regeneration of only one species characteristic of capercaillie leks - that of Oxycoccus palustris. Its occurrence after the management has increased from $80 \%$ to $82.2 \%$, and the projective cover has also increased by $20 \%$ after mowing the entire area and by $60 \%$ after mowing in a strip form.

3. Both types of ground vegetation management - the entire area mowing and mowing in a strip - have had a significant impact on the projective cover of Ledum palustre. After mowing the entire area, it has decreased by half, but after mowing in a strip, it has decreased by $30 \%$.

4. The ground vegetation mowing in a strip, compared to the entire area mowing, enhance positively the regeneration of dwarf shrubs and herbaceous vegetation.

\section{References}

1. Arhipova, I., \& Bāliņa, S. (2006). Statistika ekonomikā un biznesā (Statistics in economy and business). Rīga: Datorzinību centrs. (in Latvian)

2. Hancock, M.H., Amphlett, A., Proctor, R., Dugan, D., Willi, J., Harvey, P., \& Summers, R.W. (2011). Burning and mowing as habitat management for capercaillie Tetrao urogallus: an experimental test. Forest ecology and management, 262(3), 509-521. DOI: 10.1016/j.foreco.2011.04.019.

3. Hofmanis, H., \& Strazds, M. (2004). Medņa Tetrao urogallus L. aizsardzības plāns Latvijā (The protective plan of capercaillie Tetrao urogallus L. in Latvia). Rīga: Latvijas Ornitologijas biedrība. (in Latvian)

4. Ikauniece, S. (2017). 91D0* Bog woodland. In Ikauniece S. (Eds.) Protected habitat management guidelines for Latvia, Forests, Vol. 6, (pp. 155-167). Sigulda, Nature Conservation Agency.

5. Kalniņš, A. (1958). Medības un medību saimniecība (Game and game management). Rīga: LPSR Zinātņu akadēmija. (in Latvian)

6. Krebs, C.J. (1972). The experimental analysis of distribution and abundance. Ecology. New York: Harper and Row.

7. Lindén, H. (2002). The capercaillie - a focal species in landscape ecology at three different scales. Suomen Riista, 48, 34-45.

8. Lõhmus, A., Leivits, M., Pēterhofs, E., Zizas, R., Hofmanis, H., Ojaste, I., \& Kurlavičius, P. (2017). The Capercaillie (Tetrao urogallus): an iconic focal species for knowledge-based integrative management and conservation of Baltic forests. Biodiversity and conservation, 26(1), 1-21.

9. Muller-Dombois, D., \& Ellenberg, H. (1974). Aims and Methods of Vegetation Ecology. John Wiley \& Sons, Inc.

10. Pēterhofs, E. (2018). Ko nosedz 'Lietussargs' (What does 'umbrella' cover)? Medības. Makšk̦erēšana. Daba. Nr. 1, 32.-34. lpp. (in Latvian) 
11. Rolstad, J., \& Wegge, P. (1989). Capercaillie Tetrao urogallus populations and modern forestry - a case for landscape ecological studies. Finnish Game Research, 46, 43-52.

12. Saniga, M. (2003). Ecology of the capercaillie (Tetrao urogallus) and forest management in relation to its protection in the West Carpathians. Journal of forest science, 49(5), 229-239.

13. Spidsø, T.K., \& Stuen, O.H. (1988). Food selection by capercaillie chicks in southern Norway. Canadian Journal of Zoology, 66(2), 279-283. DOI: 10.1139/z88-041.

14. Storch, I. (1993). Habitat selection by capercaillie in summer and autumn: Is bilberry important? Oecologia, 95(2), 257-265. DOI: 10.1007/BF00323498.

15. Strazdiņa, L., Liepiņa, L., Mežaka, A., \& Madžule, L. (2011). Sūnu cel̦vedis dabas pētniekiem (Moss guide for nature researchers). Rīga: LU Akadēmiskais apgāds. (in Latvian)

16. Strazds, M., Hofmanis, H., \& Reihmanis, J. (2010). Priekšlikumi medņu riestu apsaimniekošanai Latvijā (Proposals for management of capercaillie mating places in Latvia). Rīga: Latvijas Ornitologijas biedrība (in Latvian)

17. Vasander, H., Tuittila, E.S., Lode, E., Lundin, L., Ilomets, M., Sallantaus, T., Heikkilä, R., Pitkänen, M.L., \& Laine, J. (2003). Status and restoration of peatlands in northern Europe. Wetlands ecology and management, 11(1-2), 51-63. DOI: 10.1023/A:1022061622602.

18. Zizas, R., Shamovich, D., Kurlavičius, P., Belova, O., \& Brazaitis, G. (2012). Radio-tracking of Capercaillie (Tetrao urogallus L.) in North Belarus. Baltic forestry, 18(2), 270-277. 